Eur. J. Clin. Chem. Clin. Biochem.

Vol. 31, 1993, pp. 295-301

(C) 1993 Walter de Gruyter \& Co. Berlin - New York

\title{
Determination of Lipoprotein(a): Evaluation of Three Methods
}

\author{
By W. März, ${ }^{1}$ R. Siekmeier, ${ }^{1}$ W. Groß, ${ }^{1}$ and G. M. Kostner ${ }^{2}$ \\ 1 Gustav Embden-Zentrum der Biologischen Chemie, J. W. Goethe-Universität, Frankfurt am Main, Germany \\ ${ }^{2}$ Institut für Medizinische Biochemie, Karl Franzens-Universität, Graz, Austria
}

(Received September 7, 1992/January 19, 1993)

\begin{abstract}
Summary: Lipoprotein(a) $(\mathrm{Lp}(\mathrm{a}))$ is a strong independent risk factor for premature atherosclerosis. Structurally, $\mathrm{Lp}$ (a) closely resembles LDL. Its protein moiety contains apolipoprotein B-100 and apolipoprotein(a). We evaluated two commercial enzyme immunoassays (EIAs) and an immunoradiometric assay (IRMA) for Lp(a). The three assays differed in their design and they used different antibodies. In the immunoradiometric assay, two different monoclonal antibodies were used. In the first EIA, monoclonal anti-apolipoprotein(a) was bound to the solid phase and $\mathrm{Lp}(\mathrm{a})$ was detected with polyclonal anti-apolipoprotein $\mathrm{B}(\mathrm{Lp}(\mathrm{a}): \mathrm{B}-\mathrm{EIA})$. In the second EIA, polyclonal anti-apolipoprotein(a) was used as capturing antibody and as detecting antibody (apo(a)-EIA). Ninety three plasma samples were assayed for $\mathrm{Lp}(\mathrm{a})$ with the three methods. The best correlation was obtained between the IRMA and the Lp(a):B-EIA $(r=0.971)$. Correlations between the apo(a)-EIA on the one hand and the IRMA or the Lp(a):B-EIA on the other hand were 0.889 and 0.836 , respectively. The methods significantly differed in their calibration. This resulted in different mean $\mathrm{Lp}(\mathrm{a})$ concentrations. When tested against purified $\mathrm{Lp}(\mathrm{a})$, the apo(a)-EIA appeared accurately calibrated, whereas the IRMA and the $\mathrm{Lp}(\mathrm{a}): \mathrm{B}-\mathrm{EIA}$ overestimated $\mathrm{Lp}$ (a) by approximately twofold. In the $\mathrm{Lp}(\mathrm{a}): \mathrm{B}-\mathrm{EIA}$, the detecting antibody is directed against apolipoprotein B. The Lp(a):B-EIA is, therefore, not affected by the apolipoprotein(a) size polymorphism. This allows expression of the concentration of $\mathrm{Lp}(\mathrm{a}): \mathrm{B}$ complexes on a molar basis. In contrast, the polyclonal antibody-based apo(a)-EIA measures the concentration of apolipoprotein(a) antigen, and may, therefore, be susceptible to inter- and intra-individual polydispersity of apolipoprotein(a) and $\mathrm{Lp}(\mathrm{a})$ particles. The data underline that both design and calibration of $\mathrm{Lp}(\mathrm{a})$ immunoassays are crucial.
\end{abstract}

\section{Introduction}

Lipoprotein(a) $(\mathrm{Lp}(\mathrm{a}))$ is an LDL-like particle. Its protein moiety consists of apolipoprotein $B$ and apolipoprotein(a) which are linked by a disulphide bond $(1-5)$. There is ample evidence that $\mathrm{Lp}(\mathrm{a})$ is a strong independent predictor for coronary artery disease $(6-11)$, stroke $(12,13)$, and retinal vascular occlusion (14). This has raised the demand for convenient and reliable means of quantifying $L p(a)$. So far, $L p(a)$ has been measured by a variety of methods such as radial immunodiffusion (15), electroimmunoassay $(6,16)$, zone immunoelectrophoresis (16), nephelometry (17), radioimmunoassay (18), and enzyme immunoassays (19-22).
Apolipoprotein(a) is homologous with plasminogen $(23-25)$. This has stimulated speculation that $\mathrm{Lp}(\mathrm{a})$ has an inhibitory role in fibrinolysis (26). Apolipoprotein(a) contains a variable number of plasminogen kringle 4-type units, and one copy of each a kringle 5 and a protease-like domain. Due to variations in the number of kringle 4-type repeats (27), apolipoprotein(a) displays size polymorphism $(28,29)$. The relative masses of the apolipoprotein(a) isoforms range from $M_{\mathrm{r}} 400000$ to $M_{\mathrm{r}} 700000$. Because the kringle 4-type repeats share a high degree of homology, apolipoprotein(a) is expected to contain a large number of 'repetitive' epitopes. Therefore, depending on the assay type and antibody specificity, the size 
polymorphism of apolipoprotein(a) may influence the measurement of $L p(a)$.

We here present results of a comparison of three commercial methods for the determination of $L p(a)$. The first method was an immunoradiometric assay (IRMA), based on two monoclonal antibodies recognizing apolipoprotein(a). The second method was an enzyme immunoassay (EIA), in which monoclonal anti-apolipoprotein(a) was used as capturing antibody, and detection was carried out with polyclonal anti-apolipoprotein B. The third method was also an EIA, which made use of polyclonal anti-apolipoprotein(a) as capturing as well as detecting antibody.

\section{Materials and Methods}

Two site immunoradiometric assay for apolipoprotein(a)

Antibodies and reagents were obtained as components of a test kit from Pharmacia Diagnostics AB (Uppsala, Sweden). The assay was carried out according to the instructions of the supplier. It uses two monoclonal antibodies in excess. During one-step incubation, apolipoprotein(a) reacts with the capturing antibody (cl 280) coated to Sepharose-particles, as well as with the ${ }^{125}$ I-labelled tracer (cl 356). The antigen/antibody sandwich is then separated from excess tracer by centrifugation and decantation, and the radioactivity in the pellet is counted. The assay was calibrated using standards provided with the kit. Results are reported in $U / 1$. According to the manufacturer, $\mathrm{U} / \mathrm{l}$ should correspond to $\mathrm{mg} / \mathrm{l} \mathrm{Lp}(\mathrm{a})$.

\section{Enzyme immunoassays}

Two non-competitive enzyme immunoassays were used. In the first EIA, $L p(a)$ reacts with monoclonal anti-apolipoprotein(a) on the solid phase and is then detected with polyclonal antiapolipoprotein B. This method will be referred to as Lp(a):BEIA. Reagents and microwell plates required for the $L p(a): B-$ EIA were purchased from Byk Sangtec Diagnostika (Dietzenbach, Germany). The measurements were performed according to the manufacturer's instructions. In the second EIA, polyclonal anti-apolipoprotein(a) was used as the capturing antibody, and peroxidase-labelled anti-apolipoprotein(a) was used as the detecting antibody. This assay was obtained from Immuno Diagnostika (Heidelberg, Germany). It will be referred to as apo(a)-EIA. Each EIA was calibrated using standards provided by the manufacturer. Absorbances were read on a Titertek MCC 340 microplate reader (Flow Laboratories). All EIAs were run in duplicate.

\section{Plasma samples}

Analyses were carried out in specimens from outpatients referred to the Frankfurt University Hospital for lipoprotein analysis. Blood was drawn into tubes containing EDTA $\cdot \mathrm{K}_{2}$ (final concentration: $1.5-2 \mathrm{~g} / \mathrm{l}$ ). Plasma was recovered by centrifugation. Samples were stored at $-20^{\circ} \mathrm{C}$, on average, for one, seven, and eight weeks before they were analysed with the IRMA, the apo(a)-EIA, and the Lp(a):B-EIA, respectively. Maximum storage times were 3 weeks, 16 weeks, and 17 weeks for the IRMA, the apo(a)-EIA, and the $L p(a): B-E I A$, respectively. Previous studies in which samples with intermediate and high $\mathrm{Lp}$ (a) concentrations were stored at $-20^{\circ} \mathrm{C}$ for four weeks showed that none of the methods was significantly affected by freezing and thawing.

\section{Purification of $\mathrm{Lp}(\mathrm{a})$}

$\mathrm{Lp}$ (a) was prepared from the regenerate fluid of a dextran sulphate-based LDL-apheresis system (Kanegafuchi MA 01 Liposorber LA 15) by sequential ultracentrifugation $(1.050 \mathrm{~kg} / \mathrm{l}$ and $1.125 \mathrm{~kg} / \mathrm{l}$ ) and gel filtration (30).

\section{Electrophoretic methods}

SDS-PAGE ( $\mathrm{T}=5 \%, \mathrm{C}=2.7 \%$ ) was run in a BioRad Mini Protean II cell using the buffer system of Laemmli (31). The samples were prepared by mixing $10 \mu \mathrm{l}$ plasma, $50 \mu \mathrm{l}$ electrophoresis buffer (containing $40 \mathrm{~g} / 1$ sodium dodecyl sulphate (SDS) and $31 \mathrm{~g} / 1$ dithiothreitol) and $5 \mu \mathrm{l} \beta$-mercaptoethanol. The mixtures were boiled for 5 minutes and $10 \mu \mathrm{l}$ aliquots were applied to the gels. No adjustment was made for individual $\mathrm{Lp}(\mathrm{a})$ concentrations.

Electrotransfer onto nitrocellulose (32), and immunoperoxidase staining were performed as described (33). In probing the blots, monoclonal anti-apolipoprotein(a) antibodies cl 280 (IRMA capturing antibody) and cl 356 (IRMA tracer antibody, both from Pharmacia Diagnostics $A B$, Uppsala) were used at final concentrations of $0.66 \mathrm{mg} / \mathrm{l}$. Biotinylated anti-mouse IgG and avidin : biotinylated horseradish peroxidase complex were from Vector Laboratories (Burlingame, CA) and used as recommended by the manufacturer.

\section{Statistics}

Linear regression analyses and Wilcoxon's matched-pairs signed-ranks test were carried out with SPSS $^{\mathrm{x}}$ (release $2.0+$ on UNISYS 1100/91). Non-parametric regression analysis was performed according to Passing \& Bablok (34).

\section{Results}

Two site immunoradiometric assay (IRMA)

As shown in figure 1, the two monoclonal antibodies used in the IRMA produced similar, but not identical immunoblotting patterns. Both antibodies reacted with the major apolipoprotein(a) isoforms and a large number of minor bands which are probably due to proteolytic fragmentation of apolipoprotein(a) (35, 36). Unlike the tracer antibody (cl 356), the solid phase antibody ( $\mathrm{cl} 280)$ appeared to react with protein bands having relative molecular masses of approximately $M_{\mathrm{r}} 90000$. In order to study this cross-reactivity without interference from the apolipoprotein(a) proteolytic fragments, we analysed a sample virtually lacking $\mathrm{Lp}(\mathrm{a})$. In this case, $\mathrm{cl} 280$ detected two bands, whereas $\mathrm{cl} 356$ detected none (fig. 1, panels $\mathrm{c}$ and d). When purified plasminogen was analysed by immunoblotting, an identical pattern was obtained, confirming that the capturing antibody of the IRMA reacted with plasminogen (not shown). We then examined whether this cross-reactivity could cause competition of $L p(a)$ and plaminogen for solid phase sites. In these studies, purified $L p(a)$ was mixed with plasminogen at different ratios, and $\mathrm{Lp}(\mathrm{a})$ was determined in the mixtures using the IRMA. As shown in figure 


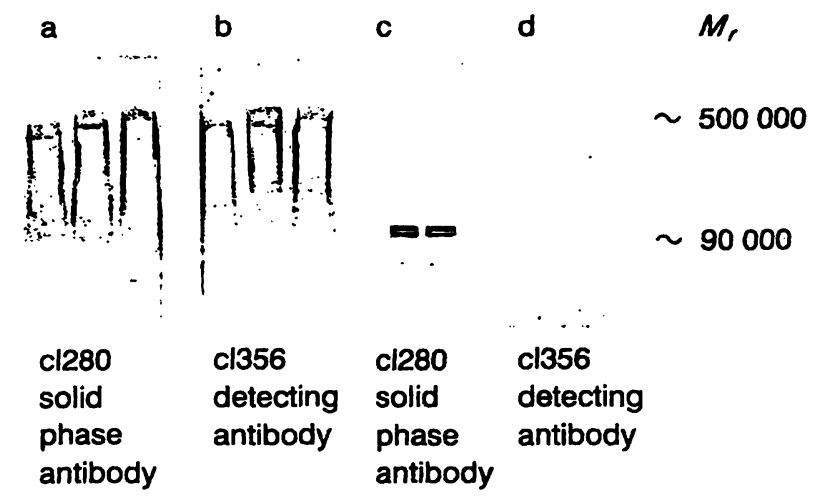

Fig. 1. Immunoblotting of apolipoprotein(a). Detection of apolipoprotein(a) was performed with monoclonal antibodies $\mathrm{cl} 280$ and $\mathrm{cl}$ 356. In the IRMA, cl 280 and cl 356 are used as solid phase and detecting antibody, respectively.

Panel a contains analyses in three samples with 340 , 420 , and $520 \mathrm{U} / \mathrm{l} \mathrm{L}$ (a) (from left to right) probed with cl 280.

Panel b shows the same samples probed with cl 365 .

In panels $c$ and $d$ a so called $L p(a)$ 'negative' sample $(\mathrm{Lp}(\mathrm{a})<10 \mathrm{U} / \mathrm{l})$ was analysed in duplicate. c was probed with cl 280 , d with cl 365 .

The experiments demonstrate that $\mathrm{cl} 280$ (the solid phase antibody in the IRMA), but not cl 356 (the detecting antibody) recognized plasminogen.

$2, \mathrm{Lp}(\mathrm{a})$ readings decreased in the presence of abnormally high plasminogen concentrations, indicating that plasminogen can displace $\mathrm{Lp}(\mathrm{a})$ from matrix binding sites. However, up to $800 \mathrm{U} / 1 \mathrm{Lp}$ (a) and 400 $\mathrm{mg} / \mathrm{l}$ plasminogen (which is about threefold the normal concentration) there was no displacement of $\mathrm{Lp}(\mathrm{a})$ from the solid phase.

\section{Intermethod comparison}

Figure 3 shows the results of $L p(a)$ determinations performed with the three methods in 93 plasma samples. There was an excellent correlation between the IRMA and the Lp(a):B-EIA $(r=0.971)$. Correlation coefficients were lower between the IRMA and the

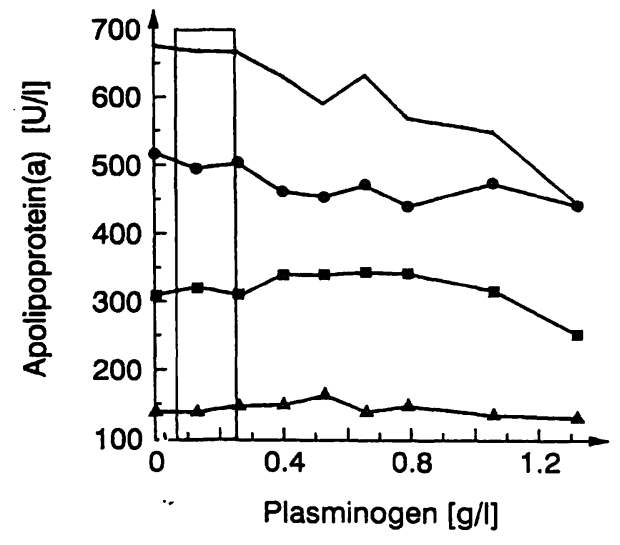

Fig. 2. IRMA for apolipoprotein(a): Interference from plasminogen. Purified $L p(a)$ was mixed with plasminogen at different ratios, and the mixtures were assayed for Lp(a) by IRMA (lot No. 28271). In the presence of high plasminogen concentrations, high $\mathrm{Lp}(\mathrm{a})$ concentrations were underestimated, indicating that plasminogen can displace $\mathrm{Lp}$ (a) from matrix binding sites.

Gray area: normal range for plasminogen.

apo(a)-EIA, and between the $\operatorname{Lp}(\mathrm{a}): \mathrm{B}$-EIA and the apo(a)-EIA (0.889 and 0.836 , respectively).

Regression lines were calculated using the least squares method and the non-parametric method proposed by Passing \& Bablok (34). For each regression line, the non-parametric method of Passing \& Bablok resulted in lower absolute values for the intercepts than the least squares method (tab. 1). Regardless of whether regression lines were estimated with the least squares or the non-parametric method, their slopes consistently indicated that the $\mathrm{Lp}(\mathrm{a})$ :B-EIA and the IRMA corresponded well, whereas the apo(a)-EIA resulted in significantly lower concentrations. This is also evident if means and medians are compared (tab. 2). The differences between the apo(a)-EIA and the other methods are striking. The difference between the Lp(a):B-EIA and the IRMA is smaller, but still significant when tested with Wilcoxon's matched-pairs signed-ranks test $(p=0.019)$.
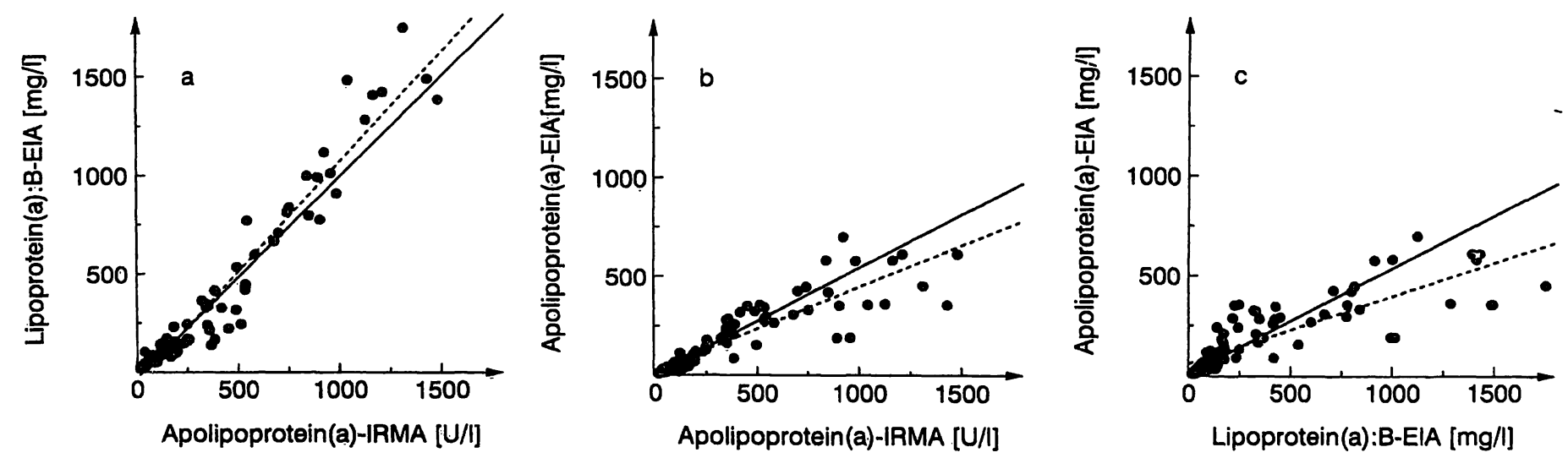

Fig. 3. Comparison of two EIAs and an IRMA for $\mathrm{Lp}(\mathrm{a})$. Determinations were carried out in parallel in 93 plasma samples. Regression lines were estimated using the least squares method (dashed) and the non-parametric method according to Passing \& Bablok (solid). For slopes and intercepts see table 1. 
Tab. 1. Comparison of three immunoassays for $L p(a)$. Regression lines calculated with the least squares method and with the non-parametric method according to Passing \& Bablok (34).

\begin{tabular}{lllllrl}
\hline Method & \multicolumn{2}{l}{$\begin{array}{l}\text { Least squares } \\
{[\mathrm{mg} / \mathrm{l}]}\end{array}$} & \multicolumn{3}{l}{$\begin{array}{l}\text { Non-parametric } \\
{[\mathrm{mg} / \mathrm{l}]}\end{array}$} \\
\cline { 2 - 7 } & $\mathrm{a}^{1}$ & $\mathrm{~b}^{1}$ & $\mathrm{r}^{2}$ & $\mathrm{a}^{1.3}$ & $\mathrm{~b}^{1.3}$ \\
\hline Lp(a):B-EIA vs IRMA & 1.12 & -52 & 0.971 & $1.02(0.94 / 1.09)$ & $-17(-29 /-3)^{4}$ \\
apo(a)-EIA vs IRMA & 0.42 & 29 & 0.889 & $0.54(0.50 / 0.60)^{5}$ & -2 \\
apo(a)-EIA vs Lp(a):B-EIA & 0.34 & 58 & 0.836 & $0.54(0.46 / 0.62)^{5}$ & $4(-1 / 14)$ \\
\hline
\end{tabular}

' $\mathrm{a}=$ slope; $\mathrm{b}=$ intercept

2 Pearson's correlation coefficient

3 in parentheses: lower and upper limits of the $95 \%$ confidence intervals as calculated according to Passing \& Bablok (34)

+ intercept significantly different from zero $(p<0.05)$

$s$ slope significantly different from unity $(p<0.05)$

Tab. 2. Comparison of immunoassays for $\mathrm{Lp}(\mathrm{a})$ in 93 plasma samples.

\begin{tabular}{llllll}
\hline Method & Mean & SD & Median & Range & $\begin{array}{l}\text { 68th percentile } \\
\text { of distances } \\
\text { from the median }\end{array}$ \\
\hline IRMA [U/1] $:$ & 353 & 363 & 191 & $17-1480$ & 192 \\
Lp(a):B-EIA [mg/l] & 344 & 420 & 142 & $17-1748$ & 186 \\
apo(a)-EIA [mg/l] & 176 & 171 & 104 & $9-701$ & 122 \\
\hline
\end{tabular}

Intra-assay and inter-assay CVs are summarized in tables 3 and 4, respectively. They show that all methods worked with satisfactory precision.

In an attempt to explain the systematic differences between the methods, we analysed standards and controls included in the test kits with each of the other methods, except that the standards used in the IRMA and the $L p(a): B-E I A$ were not tested, because they were provided in a pre-diluted form. Results are shown in table 5 . They show that the assays clearly differ in their standardization. For instance, when the calibrator of the apo(a)-EIA was analysed with the IRMA and with the Lp(a):B-EIA, results were, on average, 1.5 times and 1.6 times higher than the ex-

Tab. 3. Intra-assay precision $(n=8)$ of three immunoassays for the determination of $\mathrm{Lp}(\mathrm{a})$.

\begin{tabular}{lrrr}
\hline Method & Mean & SD & CV \\
\hline IRMA [U/l] & & & \\
sample 1 & 71.1 & 7.0 & 9.85 \\
sample 2 & 123.9 & 7.5 & 6.05 \\
sample 3 & 552.6 & 16.4 & 2.97 \\
Lp(a):B-EIA [mg/l] & & & \\
sample 1 & 37.1 & 2.6 & 6.95 \\
sample 2 & 69.6 & 1.6 & 2.36 \\
sample 3 & 358.0 & 8.1 & 2.27 \\
Apo(a)-EIA [mg/l] & & & \\
sample 1 & 50.6 & 3.1 & 6.18 \\
sample 2 & 106.6 & 8.6 & 8.10 \\
sample 3 & 264.6 & 14.1 & 5.34 \\
\hline
\end{tabular}

pected values, respectively. This was consistent with the higher $\mathrm{Lp}(\mathrm{a})$ concentrations produced by the IRMA and the Lp(a):B-EIA, compared with the apo(a)-EIA.

To determine which of the assays was the most accurate, two highly purified $\mathrm{Lp}(\mathrm{a})$ preparations were analysed with the three methods. The $\mathrm{Lp}$ (a) concentrations in these preparations were calculated from their cholesterol content, assuming cholesterol to constitute $44.5 \%$ of the $\mathrm{Lp}$ (a) particle mass. This resulted in $\mathrm{Lp}$ (a) concentrations of $438 \mathrm{mg} / 1$ and $417 \mathrm{mg} / \mathrm{l}$, respectively. With the IRMA, we found $1102 \mathrm{mg} / \mathrm{l}$

Tab. 4. Inter-assay precision of three immunoassays for the determination of $\mathrm{Lp}(\mathrm{a})$.

\begin{tabular}{|c|c|c|c|c|}
\hline Method & $\mathrm{n}$ & Mean & SD & $\mathrm{CV}$ \\
\hline \multicolumn{5}{|l|}{ IRMA [U/l] } \\
\hline Control Low ${ }^{1}$ & 15 & 129.9 & 9.0 & 6.9 \\
\hline Control High ${ }^{1}$ & 15 & 393.8 & 29.8 & 7.6 \\
\hline \multicolumn{5}{|l|}{$\mathrm{Lp}(\mathrm{a}): \mathrm{B}-\mathrm{EIA}$ [mg/l] } \\
\hline sample $\mathrm{A}^{2}$ & 9 & 96.0 & 5.1 & 5.3 \\
\hline sample $\mathrm{B}^{2}$ & 9 & 363.0 & 22.2 & 6.1 \\
\hline sample $\mathrm{C}^{2}$ & 9 & 539.7 & 34.5 & 6.4 \\
\hline \multicolumn{5}{|l|}{ Apo(a)-EIA [mg/l] } \\
\hline Low Level Control ${ }^{3}$ & 7 & 306.2 & 24.7 & 8.1 \\
\hline High Level Control ${ }^{3}$ & 7 & 414.1 & 31.2 & 7.5 \\
\hline
\end{tabular}


Tab. 5. Standardization of Lp(a) immunoassays. Analyses of commercial standards, controls, and of purified $\mathrm{Lp}(\mathrm{a})$ with three different assays.

\begin{tabular}{|c|c|c|c|c|c|c|c|}
\hline \multirow[t]{3}{*}{ Material } & \multirow{3}{*}{$\begin{array}{l}\text { Expected } \\
\text { concentra- } \\
\text { tions }\end{array}$} & \multicolumn{6}{|c|}{ Measured concentrations } \\
\hline & & \multicolumn{2}{|c|}{ IRMA } & \multicolumn{2}{|c|}{ Lp(a):B-EIA } & \multicolumn{2}{|c|}{ apo(a)-EIA } \\
\hline & & & $\mathrm{m} / \mathrm{e}^{1}$ & & $\mathrm{~m} / \mathrm{e}^{1}$ & & $\mathrm{~m} / \mathrm{e}^{1}$ \\
\hline IRMA Control High & 437 & 382 & 0.87 & 218 & 0.50 & 165 & 0.38 \\
\hline IRMA Control Low & 132 & 126 & 0.95 & 103 & 0.78 & 60 & 0.45 \\
\hline Apo(a)-EIA Low Level Control & 325 & 515 & 1.58 & 569 & 1.75 & 332 & 1.02 \\
\hline Apo(a)-EIA High Level Control & 425 & 661 & 1.56 & 535 & 1.26 & 467 & 1.10 \\
\hline Apo(a)-EIA calibrator 2 & 70 & 104 & 1.49 & 155 & 2.21 & - & n. d. ${ }^{2}$ \\
\hline Apo(a)-EIA calibrator 3 & 160 & 233 & 1.46 & 288 & 1.80 & - & n.d. \\
\hline Apo(a)-EIA calibrator 4 & 360 & 496 & 1.38 & 437 & 1.21 & - & n.d. \\
\hline Apo(a)-EIA calibrator 5 & 700 & 1125 & 1.61 & 837 & 1.20 & - & n. d. \\
\hline Purified $\mathrm{Lp}(\mathrm{a})$ preparation 1 & 438 & 1102 & 2.52 & 760 & 1.74 & 460 & 1.05 \\
\hline Purified Lp(a) preparation 2 & 417 & 1087 & 2.61 & 710 & 1.70 & 428 & 1.03 \\
\hline
\end{tabular}

Standards and controls provided by the manufacturers of three $L p(a)$ assays and two different $L p(a)$ preparations were analysed with each method. The expected concentrations are those specified by the manufacturer of the respective standard or control. In the case of purified $\mathrm{Lp}(\mathrm{a})$, the expected value was calculated from cholesterol, assuming that cholesterol constitutes $44.5 \%$ of the $\mathrm{Lp}(\mathrm{a})$ particle mass.

$1 \mathrm{~m} / \mathrm{e}$ is the ratio of the measured to the expected concentration. For instance, the Low Control supplied with the IRMA test kit was specified to contain $132 \mathrm{U} / 1$ apolipoprotein(a). When this control was analysed with the Lp(a):B-EIA, $103 \mathrm{mg} / \mathrm{l} \mathrm{Lp}(\mathrm{a})$ were found, and the $\mathrm{m} / \mathrm{e}$ ratio was 0.78 . Data for the calibrators provided with the IRMA and the Lp(a):B-EIA are not presented because these materials were provided in a pre-diluted form.

2 n. d. = not determined

and $1087 \mathrm{mg} / \mathrm{Lp}(\mathrm{a})$ in the two isolates which is more than 2.6 times greater than the expected concentration (cf. tab. 5). With the Lp(a):B-EIA, we obtained 760 $\mathrm{mg} / \mathrm{l}$ and $710 \mathrm{mg} / \mathrm{l} \mathrm{Lp}$ (a) which is 1.7 times more than expected. Finally, according to the apo(a)-EIA, the two $\mathrm{Lp}(\mathrm{a})$ preparations contained $460 \mathrm{mg} / \mathrm{l}$ and 428 $\mathrm{mg} / \mathrm{l} \mathrm{Lp}(\mathrm{a})$, respectively. Thus, the IRMA and the $\mathrm{Lp}(\mathrm{a}): \mathrm{B}-\mathrm{EIA}$ considerably overestimated $\mathrm{Lp}(\mathrm{a})$, whereas the apo(a)-EIA was accurately calibrated.

\section{Discussion}

We evaluated three commercial methods for the determination of Lp(a): an IRMA, and two non-competitive EIAs. Precision was satisfactory for all methods. The $L p(a): B-E I A$ worked with slightly lower CVs than the other methods.

The apo(a)-EIA yielded markedly lower $L p(a)$ values than the IRMA and the Lp(a):B-EIA. The differences between the methods were attributable to different calibrations of the assays. Whereas both the IRMA and the $L p(a): B-E I A$ overestimated their analyte, the apo(a)-EIA appeared accurately calibrated when tested against highly purified $L p(a)$. This is in line with earlier results from our laboratory in which the specification of a standard obtained from the manufacturer of the apo(a)-EIA was in excellent agreement with our own estimates (37). According to current opinion, $\mathrm{Lp}(\mathrm{a})$ concentrations above $300 \mathrm{mg} / \mathrm{l}$ are considered to be associated with a $2-3$ fold increase in coronary risk. If one applies this threshold value to the current study, 17 out of 93 samples would be classified differently using either the apo(a)-EIA or the IRMA (cf. tab. 6). Similarly, 15 out of the 93 samples would be. classified ambiguously with the apo(a)-EIA or with the $L p(a)$ :B-EIA. This underlines that a consensus on the standardization of $L p(a)$ immunoassays is regardly needed.

Tab. 6. Classification of 93 plasma samples according to $\mathrm{Lp}(\mathrm{a})$ concentrations obtained with different $L p(a)$ immunoassays.

\begin{tabular}{|c|c|c|c|c|}
\hline \multirow[t]{2}{*}{ Method } & \multicolumn{2}{|l|}{$\begin{array}{l}\text { IRMA } \\
{[\mathrm{U} / \mathrm{l}]}\end{array}$} & \multicolumn{2}{|c|}{$\begin{array}{l}\mathrm{Lp}(\mathrm{a}): \mathrm{B}-\mathrm{EIA} \\
{[\mathrm{mg} / \mathrm{l}]}\end{array}$} \\
\hline & $<300$ & $\geq 300$ & $<300$ & $\geq 300$ \\
\hline $\begin{array}{l}\text { Apo(a)-EIA }<300 \mathrm{mg} / \mathrm{l} \\
\text { Apo(a)-EIA } \geq 300 \mathrm{mg} / \mathrm{l}\end{array}$ & $\begin{array}{r}55 \\
0\end{array}$ & $\begin{array}{l}17 \\
21\end{array}$ & $\begin{array}{r}59 \\
2\end{array}$ & $\begin{array}{l}13 \\
19\end{array}$ \\
\hline
\end{tabular}

The three assays evaluated in this study differ in their design and the antibodies used. The IRMA is based on two monoclonal antibodies. The capturing antibody cross-reacts with plasminogen. However, because the detecting antibody does not recognize plasminogen, the assay is specific for $\mathrm{Lp}(\mathrm{a})$. Moreover, we have ruled out the possibility that, under normal conditions, competition of plasminogen and $L p(a)$ for the solid phase resulted in falsely low $\mathrm{Lp}(\mathrm{a})$ concentrations. Three to four times the normal plasminogen concentration and high $\mathrm{Lp}$ (a) concentrations have to be present, before any relevant interference occurs. 
The use of monoclonal antibodies in $\mathrm{Lp}$ (a) immunoassays may entail several problems. More than 20 genetically determined apolipoprotein(a) isoforms have been described so far. Their relative masses range from $M_{\mathrm{r}} 400000$ to $M_{\mathrm{r}} 700000$. Structurally, apolipoprotein(a) isoforms differ by the number of kringle 4 elements, which are homologous, but not identical. Only one isoform of apolipoprotein(a) containing 37 kringle 4 repeats has been cloned. It is, therefore, not known which types of kringle 4 are repeated or whether some of them are missing in smaller apolipoprotein(a) isoforms. Furthermore, there may be sequence heterogeneity in kringle 5 or the protease domain. Thus, it is conceivable that certain apolipoprotein(a) isoforms are not recognized by monoclonal antibodies. However, these considerations do obviously not apply to the IRMA used in this study. First, the good correlation between the IRMA and the $\mathrm{Lp}(\mathrm{a})$ :B-EIA makes it unlikely that one of the two assays fails to recognize a particular apolipoprotein(a) isoform. Second, among 93 samples studied none was found which gave a substantially lower signal in the IRMA (two monoclonal antibodies) than in the apo(a)-EIA (two polyclonal antibodies). Third, when antibodies cl 280 and cl 356 were used in immunoblotting experiments with different plasma samples they produced patterns identical to those obtained with polyclonal antisera (März, W., unpublished).

In this study, the $\mathrm{Lp}(\mathrm{a})$ :B-EIA correlated better with the IRMA than the apo(a)-EIA. Most likely this is due to differences in design of the EIAs. The apo(a)EIA uses the same polyclonal anti-apolipoprotein(a) as tracer and as capturing antibody. Strictly speaking, this assay measures apolipoprotein(a) mass concentration. Hence it may be influenced by the apolipoprotein(a) genetic polymorphism. Beyond this polymorphism, there is a tremendous intra-individual heterogeneity of lipoprotein(a) particles (35). It is, therefore, not very likely that apolipoprotein(a) can be measured on a molar basis, when only polyclonal anti-apolipoprotein(a) is used. In contrast, because it is suggested that there is one molecule of apolipoprotein B per $L p(a)$ particle, the $L p(a)$ :B-EIA will reflect the molar concentration of intact $L p(a): B$ complexes,

\section{References}

1. Morrisett, J. D., Guyton, J. R., Gaubatz, J. W. \& Gotto jr., A. M. (1987) Lipoprotein (a): structure, metabolism, and epidemiology, In: New Comprehensive Biochemistry (Neuberger, A. \& van Deenen, L. L. M., eds.) Vol. 14. Plasma Lipoproteins (Gotto jr., A. M., ed.) pp. 129-152, Elsevier, Amsterdam. irrespective of the apolipoprotein(a) isoform. A potential drawback of assays using anti-apolipoprotein $B$ as detecting antibody is that $L p(a)$ may be overestimated due to the presence of complexes between $\mathrm{Lp}(\mathrm{a})$ and $\mathrm{LDL}(38,39)$. However, in solid phase immunoassays, this may not be a major problem, because incubations are performed in the presence of non-ionic detergents which may dissociate $\mathrm{Lp}(\mathrm{a})-\mathrm{LDL}$ complexes.

As mentioned before, the IRMA excellently correlated with the $L p(a)$ :B-EIA. This suggests that not only the $\mathrm{Lp}(\mathrm{a})$ :B-EIA, but also the IRMA estimated Lp(a):B particle concentration rather than apolipoprotein(a) mass concentration. Since two monoclonal antibodies for apolipoprotein(a) are used in the IRMA, the tracer antibody must recognize an epitope present once per apolipoprotein(a) molecule. Such an epitope is more likely to be located in kringle 5 or the protease-like domain of apolipoprotein(a) than in the repetitive kringle 4. As a consequence, the IRMA should be insensitive to variations in the number of kringle 4 repeats, i. e. apolipoprotein(a) size polymorphism.

In summary, these data show that there are still many unresolved problems concerning the measurement of $\mathrm{Lp}(\mathrm{a})$. Design and antibodies have strong impacts on $\mathrm{Lp}$ (a) assays. Methods reflecting particle concentration such as the IRMA or the Lp(a):B-EIA are insensitive to apolipoprotein(a) heterogeneity. In solid phase binding assays using anti-apolipoprotein(a) as capturing antibody and anti-apolipoprotein B as detecting antibody, cross-reactivity with plasminogen is not a major concern. In further attempts to standardize the measurement of $L p(a)$, major efforts should therefore be devoted to this type of assay. As results of $\mathrm{Lp}$ (a) assays may differ by more than $100 \%$ these attempts should be made soon.

\section{Acknowledgement}

The authors thank Mrs. Sabine Black, Mrs. Bettina Donnerhak, and Mrs. Ulrike Stein for expert technical assistance. They are indebted to Pharmacia Diagnostics $A B$ for providing the apolipoprotein(a)-specific monoclonal antibodies cl 280 and $\mathrm{cl} 356$. Parts of this study were supported by a grant from the Austrian Research Foundation, grant No. S-46-01 to G.M.K.
2. Utermann, G. (1989) The mysteries of lipoprotein (a). Science $246,904-910$.

3. Fless, G. M., ZumMạllen, M. E. \& Scanu, A. M. (1986) Physicochemical properties of apolipoprotein (a) and lipoprotein (a) derived from the dissociation of human plasma lipoprotein (a). J. Biol. Chem. 261, 8712-8718. 
4. Armstrong, V. W., Walli, A. K. \& Seidel, D. (1985) Isolation, characterization, and uptake in human fibroblasts of an apo(a)-free lipoprotein obtained on reduction of lipoprotein(a). J. Lipid. Res. 26, 1314-1323.

5. Sommer, A., Gorges, R., Kostner, G. M., Paltauf, F. \& Hermetter, A. (1991) Sulfhydryl-selective fluorescence labeling of lipoprotein (a) reveals evidence for one single disulfide linkage between apoproteins (a) and B-100. Biochemistry 30, 11245-11249.

6. Kostner, G. M., Avogaro, P., Cazzolato, G., Marth, E. \& Bittolo-Bon, G. (1981) Lipoprotein Lp(a) and the risk for myocardial infarction. Atherosclerosis 38, 51-61.

7. Dahlen, G. H., Guyton, J. R., Attar, M., Farmer, J. A., Kautz, J. A. \& Gotto jr., A. M. (1986) Association of levels of lipoprotein $\mathrm{Lp}(\mathrm{a})$, plasma lipids, and other lipoproteins with coronary artery disease documented by angiography. Circulation 74, 758-765.

8. Armstrong, V. W., Cremer, P., Eberle, E., Manke, A., Schulze, F., Wieland, H., Kreuzer, H. \& Seidel, D. (1986) The association between serum $\mathrm{Lp}(\mathrm{a})$ concentrations and angiographically assessed coronary atherosclerosis. Dependence on serum LDL levels. Atherosclerosis 62, 249257.

9. Seed, M., Hoppichler, F., Reaveley, D., McCarthy, S., Thompson, G. R., Boerwinkle, E. \& Utermann, G. (1990) Relationship of serum lipoprotein (a) concentration and apolipoprotein (a) phenotype to coronary heart disease in patients with familial hypercholesterolemia. New Engl. J. Med. 322, $1491-1499$.

10. Wiklund, O., Angelin, B., Olofsson, S.-O., Eriksson, M., Fager, G., Berglund, L. \& Bondjers, G. (1990) Apolipoprotein (a) and ischemic heart disease in familial hypercholesterolemia. Lancet 335, 1360-1363.

11. Sandkamp, M., Funke, H., Schulte, H., Köhler, E. \& Assmann, G. (1990) Lipoprotein (a) is an independent risk factor for myocardial infarction at a young age. Clin. Chem. $36,20-23$.

12. Jürgens, G. \& Költringer, P. (1987) Lipoprotein(a) in ischemic cerebrovascular disease: A new approach to the assessment of risk for stroke. Neurology 37, 513-515.

13. Zenker, G., Költringer, P., Boné, G., Niederkorn, K., Pfeiffer, K. \& Jürgens, G. (1986) Lipoprotein(a) as a strong indicator for cerebrovascular disease. Stroke 17, 942-945.

14. Müller, H. M., Diekstall, F. F., Schmidt, E., März, W., Canzler, H. \& Demeler, U. (1992) Lipoprotein (a): A risk factor for retinal vascular occlusion. German J. Ophthalmol. $1,338-341$.

15. Albers, J. J. \& Hazzard, W. R. (1974) Immunochemical quantification of human plasma $\mathrm{Lp}$ (a) lipoprotein. Lipids $9,15-27$

16. März, W. \& Groß, W. (1983) Quantification of human serum lipoprotein $\mathrm{Lp}(\mathrm{a})$ : Zone immunoelectrophoresis assay, a new sensitive method, as compared to electroimmuno assay. Clin. Chim. Acta 134, 265-279.

17. Cazzolato, G., Prakasch, G., Green, S. \& Kostner, G. M. (1983) The determination of lipoprotein $L p(a)$ by rate and endpoint nephelometry. Clin. Chim. Acta 135, 203-208.

18. Albers, J. J., Adolphson, J. L. \& Hazzard, W. R. (1977) Radioimmunoassay of human plasma Lp(a) lipoprotein. J. Lipid Res. 18, 331-338.

19. Gaubatz, J. W., Cushing, G. L. \& Morrisett, J. D. (1986) Quantitation, isolation, and characterization of human lipoprotein (a), In: Plasma Lipoproteins. Part B. Characterization, Cell Biology, and Metabolism (Albers, J. J., Segrest, J. P., eds.) Methods in Enzymology (Colowick, S. P. \& Kaplan, N. O., eds.) Vol. 129, Orlando, Academic Press Inc., pp. $167-186$.

20. Duvic, C. R., Smith, G., Sledge, W. E., Lee, L. T., Murray, M. D., Roheim, P. S., Gallaher, W. R. \& Thompson, J. J. (1985) Identification of a mouse monoclonal antibody, LHLP-1, specific for human Lp(a). J. Lipid Res. 26, $540-$ 548.
21. Labeur, C., Michiels, G., Bury, J., Usher, D. C. \& Rosseneu, M. (1989) Lipoprotein(a) quantified by an enzyme-linked immunosorbent assay with monoclonal antibodies. Clin. Chem. 35, 1380-1384.

22. Vu Dac, N., Mezdour, H., Parra, H. J., Luc, G., Luyeye, I. \& Fruchart, J. C. (1989) A selective bi-site immunoenzymatic procedure for human $L p(a)$ lipoprotein quantification using monoclonal antibodies against apo(a) and apoB. J. Lipid. Res. 30, 1437-1443.

23. Eaton, D. L., Fless, G. M., Kohr, W. J., McLean, J. W., Xu, Q.-T., Miller, C. G., Lawn, R. M. \& Scanu, A. M. (1987) Partial amino acid sequence of apolipoprotein (a) shows that it is homologous to plasminogen. Proc. Natl. Acad. Sci. USA 84, 3224-3228.

24. McLean, J. W., Tomlinson, J. E., Kuang, W.-J., Eaton, D. L., Chen, E. Y., Fless, G. M., Scanu, A. M. \& Lawn, R. M. (1987) cDNA sequence of human apolipoprotein (a) is homologous to plasminogen. Nature 330, 132-137.

25. Kratzin, H., Armstrong, V. W., Niehaus, M., Hilschmann, N. \& Seidel, D. (1987) Structural relationship of an apolipoprotein (a) phenotype $(570 \mathrm{kd})$ to plasminogen: Homologous kringle domains are linked by carbohydrate-rich regions. Biol. Chem. Hoppe-Seyler 368, 1533-1544.

26. Miles, L. A. \& Plow, E. F. (1990) Lp(a): An interloper into the fibrinolytic system? Thromb. Haemostas. 63, 331-335.

27. Koschinsky, M. L., Beisiegel, U., Henne-Bruns, D., Eaton, D. L. \& Lawn, R. M. (1990) Apolipoprotein (a) size heterogeneity is related to variable number of repeat sequences in its mRNA. Biochemistry 29, 640-644.

28. Utermann, G., Kraft, H. G., Menzel, H. J., Hopferwieser, T. \& Seitz, C. (1988) Genetics of the quantitative Lp(a) lipoprotein trait. I. Relation of $\mathrm{Lp}(\mathrm{a})$ glycoprotein phenotypes to $\mathrm{Lp}(\mathrm{a})$ lipoprotein concentrations in plasma. Hum. Genet. 78, 41-46.

29. Drayna, D. T., Hegele, R. A., Hass, P. E., Emi, M., Wu, L. L., Eaton, D. L., Lawn, R. M., Williams, R. R., White, R. L. \& Lalouel, J.-M. (1988) Genetic linkage between lipoprotein(a) phenotype and a DNA polymorphism in the plasminogen gene. Genomics 3, 230-236.

30. März, W., Groß, E., Siekmeier, R., Scharrer, I. \& Groß, W. (1991) A simple method for the isolation of large quantities of lipoprotein (a). Thromb. Haemostas. 65, 792 (Abstract).

31. Laemmli, U. K. (1970) Cleavage of structural proteins during assembly of the head of bacteriophage T4. Nature $227,680-685$.

32. Towbin, H., Staehlin, T. \& Gordon, J. (1979) Electrophoretic transfer of proteins from polyacrylamide gels to nitrocellulose sheets: Procedure and some applications. Proc. Natl. Acad. Sci. USA 76, 4350-4354.

33. März, W., Cezanne, S. \& Groß, W. (1991) Immunoblotting of apolipoprotein $\mathrm{E}$ in immobilized $\mathrm{pH}$ gradients. Electrophoresis $12,59-63$.

34. Passing, H. \& Bablok, W. (1983) A new biometrical procedure for testing the equality of measurements from two different analytical methods. J. Clin. Chem. Clin. Biochem. $21,709-720$.

35. März, W., Siekmeier, R. \& Groß, W. (1991) Heterogeneity of lipoprotein (a): structural and immunological characterization of $\mathrm{Lp}$ (a) size isomorphs. Thromb. Haemostas. 65, 714 (Abstract).

36. Oida, K., Takai, H., Maeda, H., Takahashi, S., Shimada, A., Suzuki, J., Tamai, T., Nakai, T. \& Miyabo, S. (1992) Apolipoprotein (a) is present in urine and its excretion is decreased in patients with renal failure. Clin. Chem. 38, 2244-2248.

37. März, W., Siekmeier, R., Groß, E. \& Groß, W. (1993) Determination of Lp(a): Enzyme immunoassay and immunoradiometric assay compared. Clin. Chim. Acta, in press. 
38. Trieu, V. N., Zioncheck, T. F., Lawn, R. M. \& McConathy, W. J. (1991) Interaction of apolipoprotein (a) with apoli= poprotein B-containing lipoproteins. J. Biol. Chem. 266, $5480-5485$.

\section{Note added in proof}

On the basis of the results presented in this article, the calibration of the Lp(a):B-EIA will be revised by the manufacturer.
39. Trieu, V. N. \& McConathy, W. J. (1990) Lipoprotein (a) binding to other apolipoprotein B containing lipoproteins. Biochemistry 29, $5919-5924$.

Dr. Winfried März Gustav Embden-Centeri of Biological Chemistry University Hospital

J. W. Goethe-University

Theodor Stern-Kai 7

W-6000 Frankfurt/Main

Germany 